\title{
Ethics as a Motivation Indicator in Second Language Vocational Digital Teaching
}

\author{
Natalya Viktorovna Matveeva*, Ludmila Vladimirovna Makar
}

The Linguodidactics Department, Institute of Humanities, Russian University of Transport (MIIT), 9, bld. 9, Obrazcova Street, Moscow, 127994, Russia

\begin{tabular}{l} 
A R T I C L E I N F O \\
\hline Article history: \\
Received: 31 March, 2020 \\
Accepted:12 May, 2020 \\
Online: 28 August, 2020 \\
\hline Keywords: \\
College Students \\
Computer Games Development \\
Ethical Teaching Skills \\
Foreign Language \\
Out-Of-Classroom Autonomous \\
Activity \\
Teacher-Student Rapport
\end{tabular}

\section{Introduction}

This paper is an extension of work originally presented in Proceedings 2019 International Conference "Quality Management, Transport and Information Security, Information Technologies" (IT\&QM\&IS). It stated that there existed the gap between college and university syllabus in the number of professionally oriented themes (not in favour of college students); individual words learnt ( $\approx 800$ at college vs 600 at university); and in learning methods. In addition, it has been revealed that college students underestimate the role of searching information online, critical thinking, making quick decisions and some other basic competences and skills as essential for their future career. The language computer games to overcome the differences were

${ }^{*}$ Corresponding Author: Natalya Matveeva, Russian University of Transport (MIIT),+79262460543, matveevanv@mail.ru developed in Adobe Animate, and their plot and the interface design were described [1].

The piloting research was initiated at Serpukhov college (Moscow Region, Russia). The college is comprehensive with approximately 1400 students from the south of Moscow region and adjacent areas of Tula and Kaluga regions mastering a wide range of specialities. All of them were invited to take part in the games. However, due to the geographically dispersed location of the college faculties, for the purpose of adequate data collection in part of classroom discussions we managed to keep in close touch only with the students of engineering specialities who study in one of the premises (450). This is why we consider this group of students the core of our research and the research itself piloting.

The first invitation to bridge the gap through the games was placed on the college official Internet-site at the beginning of the academic year. It offered a brief thematic review of the games and 
description of test conditions. Students were informed that we would be glad if they shared the results with us sending screenshots of their game certificates to the contact e-mail. We also organized a public page in a social network in case the students wanted to discuss gameplay. The English teachers of Serpukhov college duplicated information in classes. Even a month later there was no great activity surge, and we found out that this new type of learning activity was not welcome by students with their arms outstretched.

The question followed: as information technology itself and the intriguing form of presenting educational materials such as educational computer game couldn't be the dominating motives for college students in their independent work in learning English as a second language, a teacher should ethically motivate them to study.

Ethics in teaching profession attracts attention of the professional community. The quality of a teacher is directly connected to setting a good moral example for students and the skills of acting in accord with professional ethical standards [2,3]. In Russia researchers challenge the task of developing pedagogical ethics in order to make the educational process more effective [4]. A need for continuous teacher training to develop ethical competency is highly emphasized [5-7]. The teacher's ethical competency is thought to comprise, firstly, the knowledge of ethics and ethical aspects in teaching, secondly, skills of pedagogical interaction and communication, thirdly, the ability to implement the knowledge of ethics in specific pedagogical situations. Among ethically sound personal qualities in teaching, tolerance, poise, goodwill, caring attitude, and the ability to empathize appear to be the most representative ones [8]. Teaching ethically in a digital environment is of great importance as well. Exactly this aspect of teaching ethics is in the focus of our research.

\section{Problem Statement}

It has been found out that the teacher's personality can have a major long-term impact on students' motivation to learn a second language, including autonomous, or as Lamb \& Wedell said, "in their own time, of their own volition beyond the classroom" [9] learning. Melyokhina \& Bobohodzhaeva highlighted that learners are particularly inspired by teachers who are content competent and able to build good teacher-student rapport, demonstrate academic literacy and interest in teaching [10]. Thus, the issue of teaching ethics as a factor motivating students to study is becoming a research agenda.

In college and university educational context, where the second language is a mandatory, non-elective job-oriented course and teachers have to face mixed ability and mixed motivation classes, the issue of motivating students is of the utmost importance. A great number of motivators having been scrutinized by the teaching community worldwide [11], still potentially effective ones must be revealed and investigated.

\section{Research Questions}

Without minimizing the significance of ethical knowledge and ethically sound personal qualities of a teacher in developing students' learning motivation, we tend to attribute a greater deal of success in this field to the practical skills of applying these two in such fundamental pedagogical situations as 1) designing and implementing language learning courses, classes, materials and activities and 2) building relationships with students. As to the designing tasks, it is generally accepted that informing learners about the aims, providing them with information meaningful to them, using facilitating instructional techniques to perform and achieve goals, etc. is ethical. When building rapport with students, it is ethical to respect their rights, dignity and freedom, their autonomy and privacy, to avoid conflicts, provide choice, timely and objective assessment of works, give informational feedback.

Using this line of thinking, we raised the question as to whether these teaching skills with strongly felt ethical background can play into the college teachers' hands to engage the learners into autonomous training aimed to compensate an existing gap between college and university syllabus in the number of 1) professionally oriented themes (not in favour of college students); 2) individual words learnt $(\approx 800$ at college vs 600 at university); 3 ) in learning methods. In addition, it has been revealed that college students underestimate the role of searching information online, critical thinking, making quick decisions and some other basic competences and skills as essential for their future career [12].

\section{Purpose of the Study}

The objective of this research is to collect empirical data and ascertain the degree of motivational power of ethical teaching skills in conducting out-of-classroom learning activities at college. For the purpose, we 1) conceptualize the ethical teaching skills of primary importance when creating and using an autonomous learning activity in the form of a computer game; 2) analyse their possible influence on second language learning motivation of college students.

\section{Research Methods}

Below we outline two sets of ethical teaching skills corresponding to the pedagogical situations mentioned which are of high value in digital environment.

\subsection{Ethical Skills Important for Designing and Implementing Learning Materials and Activities}

Using extra-curricular interests, skills and competences. When designing materials and activities for autonomous language learning, it is essential to provide for bringing different interests and skills students may have a good command of, these may be drawing, love for sport or IT. While choosing the ones we could rely upon, what we were quite sure of is that the absolute majority of our students are quite competent in computers and digital technologies. The rich virtual environment offers what young people appreciate: simulations, games, digital objects, communication tools. It is natural then to choose students' IT competence for designing autonomous English learning activities.

Providing information meaningful for students. Due to the characteristics of their age group college students are not inclined to work for the long-term perspective. Their life and professional trajectory are far from being clear and well defined. In their free time, they are more fascinated with "having fun", which in fact means communicating with friends and trying new or pleasurable things to do. 
Our games are quite in this vein. The topics for the games "The Era of Great Geographical Discoveries: Meeting of Civilizations" and "Arctic Convoys of the Second World War" concern the watershed periods in human history. Being new, they suggest a challenge to be engaged in indirect communication with antecedent generations and civilizations through conceptual thinking and problem solving, acquire and share knowledge of them. Moreover, remembering Macmurray [13], who pleaded for online educational systems based on "learning to be human", we can say the games implement the humanistic approach based on human perception, communication and interaction, which are also the key to the field of learning languages.

Instructional context providing, following Walters' words [14], "choice, optimal challenge, informational feedback, interpersonal involvement, and acknowledgement of feelings" can play a great part in motivating L2 learners. The skill to provide the instruction of this kind is an ethical challenge for a teacher.

We provide a full-range instruction set on the splash screen of each game. It briefly describes the theme, plot and gameplay, states the main aim of each game, informs about helpful Internet resources and the systems of controls for successful playing. The instruction gives a clear rationale that allows participants to fully grasp the specific meaning and importance of the activity.

Utility value of the games designed proceeds from the research task to bridge the gap between college and university foreign language curricula. The themes of the games raise issues on sociology, psychology, culture and religion, communication, economic systems, which are not included in the syllabus at colleges, and also concern civilized values in general - war and peace, independence, non-intervention, friendship, cooperation, poverty and prosperity. Besides language and learning skills, the games promote college students' digital literacy, life, research and professional skills such as navigating, interacting, searching information online, quick reading and making decisions. All kinds of skills gained will benefit college graduates both if they decide to continue education at university and if they go straight to work.

\subsection{Ethical Skills Important for Teacher-Student Relationship}

Respect for autonomy. Autonomy, according to Noels [15] and some other researcher such as Lozovoy \& Zashchitina [16], refers to "a sense that one can freely choose to engage in activities that they find personally meaningful. Teacher's autonomy enhancing behavior includes fostering relevance, allowing criticism and providing choice [17]. We followed the advice of Jang, Reeve \& Deci [18] to use informational language that provides options for students and identifies the potential meaningfulness of the activity suggested. We highlighted that the games comprised professionally oriented tasks, and the knowledge and skills students had acquired during their studies at college would help them as players to survive in the game worlds currently and as specialists in the future. The tasks were specifically designed for players to form good generalizations about what will work well when they face more complex professional and life challenges.

Commitment to success means a student's willingness to engage in and persist at a task (Wolters, 2003). In order to sustain engagement and persistence in the games we foresaw the possibility for the participants to play through the games again if the score does not satisfy them, simultaneously drilling the words and memorising the answers thus climbing to game and academic success.

Feedback. In-class short discussions were organized to see how much interest the games provoked, find out the difficulties and drawbacks, and promote learners' sense of competence. Students were motivated to express their opinions about the games. Some reactions just needed explanations or encouragement from the teachers, while others resulted in a forthcoming hot round-table discussion on the topics the games offered. Some of the students demonstrated involvement, immediacy and interest. They provided help to those who experienced difficulties whether IT or English course based. The feedback then was threefold: from students to the teachers, from the teachers to the students, and between students.

Evaluation brings up an issue of rewards. To be effective, rewards need to be valued by their potential recipients and timely administered. Making voluntary participation and confidentiality the corner-stones of the activity, we avoided the necessity of extrinsic rewards, which have been found to interfere with the process and quality of learning (Reeve, 2005). Two kinds of evaluation were ensured, namely, direct individual clear-eyed assessment and indirect, implied self-evaluation. The former was provided by scoring and timing programmed for the whole game. The score and time spent in a game are shown in the last frame, which is also the learner's certificate. The latter was supposed to arouse during feedback in-class sessions. Although these sessions pursued a different goal (see above), it is difficult to argue the possible outbreak of latent self-assessment thoughts as a result of comparing one's own actions with those of groupmates. In both cases, students did not have to share their results with anyone keeping them private if timid or unsatisfied.

Confidentiality. Some students felt comfortable and were not shy to share their scores without being forced. Nevertheless, we strictly followed this principle regarding those students who showed no inclination to discuss anything related to the activity. We did not experience personal data collection, we did not pursue students who refused to take part in the activities, just we were happy for those who had passed the games and shared the score with us.

\section{Procedure}

We were allowed to deliver information about the computer games developed to fill the gap in learning functional lexis during the buzz session with Sergey Chekmaev, the Russian sciencefiction writer and a participant of literary adaptation of numerous computer games, TimeZero, Destiny, StarQuake being some of them. The audience of the session, as we saw it, was the students who were "computer game players" and we hoped exactly these ones were the vanguard open to innovations.

Students could launch the games any time they wanted during five-month period starting from the first announcement.

Short classroom feedback took place once a fortnight at the lessons, their duration depending on the number of questions on procedural and rule matters the students had. 
N.V. Matveeva et al. / Advances in Science, Technology and Engineering Systems Journal Vol. 5, No. 4, 776-782 (2020)

The issues raised by the topics of the games were discussed during final round table talks when the students discussed and argued the topics-related issues. During these talks students' L2 and human progress was reviewed.

After this debriefing the site was not closed and had more visitors in the spring and during the summer holidays.

Having conceptualised ethical issues of primary importance when creating and using educational computer games as learning activities we monitored their possible influence on students' L2 learning motivation by means of quantitative and qualitative methods.

To do statistics we processed data from 1) Metrika.Yandex, which is the analytical widget installed on the site to count unique IPs and the number of visits, to fix the non-personalised data regarding the traffic, geography, age of the visitors and time spent on the site available and 2) the students' certificates submitted. Only results proved by certificates sent by emails or VKontakte were subject to the analysis. The certificates shown but not sent were neglected.

The qualitative analysis is based on the students' questions and comments expressed orally during classroom feedback sessions or committed in writing (mostly in English!) via e-mail, VKontakte or directly to the teachers and sorting them out in accordance with the ethical aspects listed above. During these sessions the students could express their main motives why they played the games explicitly, and some of them did. This gave us an opportunity to disclose the motivation these students had. Data retrieved are presented in the tables below.

\section{Findings}

This section presents data retrieved through the investigation: the total number of unique IPs and the total number of visits; students' scores.

Table 1: Statistical data retrieved from Metrika.Yandex

\begin{tabular}{|l|l|}
\hline The number of unique IPs & The number of views \\
\hline 275 & 692 \\
\hline
\end{tabular}

Table 2: Non-personalized students' scores

\begin{tabular}{|l|l|l|l|}
\hline Certificate & Score, \% & Motivation & $\begin{array}{l}\text { Time } \\
\text { spent } \\
\text { online, } \\
\text { min. }\end{array}$ \\
\hline 1 & 92 & Positive attitude to life & 6 \\
\hline 2 & 90 & Computer game player & 1 \\
\hline 3 & 88 & Computer game player & 1 \\
\hline 4 & 80 & Entering a university & - \\
\hline 5 & 80 & Computer game player & 16 \\
\hline 6 & 80 & $\begin{array}{l}\text { Investigation for } \\
\text { cheating }\end{array}$ & - \\
\hline 7 & 77 & Computer game player & - \\
\hline 8 & 74 & Computer game player & 1 \\
\hline 9 & 71 & Interest to the topics & 9 \\
\hline 10 & 68 & Interest to the topics & 5 \\
\hline 11 & 67 & Inclination to success & 9 \\
\hline 12 & 61 & Computer game player & 17 \\
\hline
\end{tabular}

\begin{tabular}{|c|c|c|c|}
\hline 13 & 60 & $\begin{array}{l}\text { High interest to } \\
\text { learning English }\end{array}$ & 17 \\
\hline 14 & 51 & Social activist & 5 \\
\hline 15 & 50 & $\begin{array}{l}\text { General interest to IT } \\
\text { as a speciality }\end{array}$ & 12 \\
\hline 16 & 50 & $\begin{array}{l}\text { High interest to } \\
\text { learning English }\end{array}$ & 19 \\
\hline 17 & 49 & Computer game player & 9 \\
\hline 18 & 48 & Computer game player & 12 \\
\hline 19 & 48 & $\begin{array}{l}\text { General interest to IT } \\
\text { as a speciality }\end{array}$ & 20 \\
\hline 20 & 47 & $\begin{array}{l}\text { Investigation } \\
\text { cheating }\end{array}$ & 20 \\
\hline 21 & 47 & $\begin{array}{l}\text { General interest to IT } \\
\text { as a speciality }\end{array}$ & 9 \\
\hline 22 & 44 & Curiosity & 4 \\
\hline 23 & 40 & $\begin{array}{l}\text { General interest to IT } \\
\text { as a speciality }\end{array}$ & 16 \\
\hline 24 & 31 & Interest to the topics & - \\
\hline 25 & 28 & Interest to the topics & - \\
\hline 26 & 28 & Social activist & 15 \\
\hline 27 & 26 & Interest to the topics & 6 \\
\hline 28 & 26 & $\begin{array}{l}\text { General interest to IT } \\
\text { as a speciality }\end{array}$ & 2 \\
\hline 29 & 26 & Computer game player & 6 \\
\hline 30 & 25 & Curiosity & - \\
\hline 31 & 23 & Computer game player & 6 \\
\hline 32 & 23 & Interest to the topics & 5 \\
\hline 33 & 20 & $\begin{array}{l}\text { General interest to IT } \\
\text { as a speciality }\end{array}$ & 4 \\
\hline 34 & 20 & Knock-on effect & - \\
\hline 35 & 16 & Social activist & 9 \\
\hline
\end{tabular}

Table 3. Students' Questions and Comments Grouped by Ethical Skills Involved

\begin{tabular}{|c|c|c}
\hline No & Ethical Skill & $\begin{array}{c}\text { Students' question and } \\
\text { comments }\end{array}$ \\
\hline
\end{tabular}

Ethical Skills Important for Designing and Implementing Learning Materials and Activities

\begin{tabular}{|l|l|l|}
\hline 1 & $\begin{array}{l}\text { Using extra- } \\
\text { curriculum (in this } \\
\text { research: IT) interests, } \\
\text { skills and competences }\end{array}$ & $\begin{array}{l}\text { How should I activate the } \\
\text { game? Can I play the game } \\
\text { using a mobile phone? What } \\
\text { should I do to get rid of } \\
\text { advertising banners on the site? } \\
\text { What should I do to start } \\
\text { playing? I type in the correct } \\
\text { word but the score doesn't } \\
\text { improve. }\end{array}$ \\
\hline 2 & $\begin{array}{l}\text { Providing information } \\
\text { meaningful for } \\
\text { students }\end{array}$ & $\begin{array}{l}\text { Do you think a peaceful } \\
\text { meeting of civilization } \\
\text { possible? Is it possible to help } \\
\text { the Arctic convoy survive in a } \\
\text { game? }\end{array}$ \\
\hline 3 & Instructional context & $\begin{array}{l}\text { How to pass the game } \\
\text { through? What is it necessary } \\
\text { to do there? Where should I }\end{array}$ \\
\hline
\end{tabular}




\begin{tabular}{|c|c|c|}
\hline & & $\begin{array}{l}\text { get information on the topic? } \\
\text { Should I know everything } \\
\text { included into the game? }\end{array}$ \\
\hline 4 & Utility value & $\begin{array}{l}\text { Do we help you (a teacher) in } \\
\text { anything? Do you (a teacher) } \\
\text { want us to play? Are you (a } \\
\text { teacher) preparing a report? }\end{array}$ \\
\hline \multicolumn{3}{|c|}{ Ethical Skills Important for Teacher-Student Relationship } \\
\hline 5 & Respect for autonomy & $\begin{array}{l}\text { The control system is too } \\
\text { complicated. I didn't manage } \\
\text { to catch the point. Is it a } \\
\text { compulsory or voluntary } \\
\text { activity? No desire to be } \\
\text { measured again. }\end{array}$ \\
\hline 6 & $\begin{array}{l}\text { Commitment to } \\
\text { success }\end{array}$ & $\begin{array}{l}\text { I've passed through the game } \\
\text { several times (12) and didn't } \\
\text { get a score I can share. }\end{array}$ \\
\hline 7 & Evaluation & Is it possible to cheat? \\
\hline 8 & Confidentiality & $\begin{array}{l}\text { Have you passed through the } \\
\text { game, my groupmate? Do you, } \\
\text { teacher, need help? }\end{array}$ \\
\hline
\end{tabular}

\section{Discussion}

Below we suggest our interpretation of the statistical data and students' reactions to the activities received with a glance to their personalities and conclusions we have come to.

Using extra-curriculum interests, skills and competences. Initially we supposed the students' high IT competence in general and in computer games particularly. However, their questions (table 3) displayed that some IT areas were underdeveloped, among them 1) operating some software programmes, namely, Adobe Flash Player; 2) understanding that the Internet is an unrestricted advertising media; 3) unskillful situational manipulating with a keyboard and a mouse.

Providing information meaningful for students. The games content proved to be topical. The possibility of a peaceful meeting of civilization caused a really hot classroom discussion as well as the alternative for the Arctic convoy PQ-17 to do the 'the Russian run' and survive. The students' willingness to put their opinions on the lessons the humankind learnt made us certain that we had chosen information which was of interest to our students provoking critical thinking and arguing the point of view.

Questions dealing with instructional context testify to its particular importance and indicate the necessity of its provision more than once and in different forms. In addition, the technological difficulties students experienced with the software, advertising, etc. made us think of the necessity to cover them in a written form, too, thus providing sufficient guidance and support throughout the entire process of participation.
The in-lead about the utility value of the games brought the students to speculations about their future jobs and responsibilities, the difference between college and university educational routes and subsequent careers being clearly understood. In their turn, students showed their sincere interest to the utility value of the games for us, teachers. They tried to discover if we had any personal motivation for the work done other than declared. Here we felt the interdependence of teaching and learning motivations, the so-called knock-on effect described in a number of research $[19,20]$.

As we have repeatedly stressed, we did not press the students to play, it's them who decided. This respect for autonomy was a novelty for them used to compulsory activities. Students returned to this aspect, expressing no desire to be measured and assessed again. This is quite in line with Huang, Han, \& Schnapp's conclusions [21] that state standardised testing regimes cause a strong concern. Assured that the activity was voluntary, some of such students participated, not sharing the score though.

Commitment to success ranged from very high (some students passed through the game up to twelve times) to extremely low when the students refused to finish the games alleging technical difficulties, for example, complicated control system. It is interesting to note that it took only one minute to make two of the best scores $(90 \%$ and $88 \%$ ), while the winner $(92 \%)$ spent 6 minutes online (table 2). The winners evidently had passed through the game several times, memorizing the answers and drilling the words. The six of the worst results $(20-26 \%)$ were also received with little time spent in a game (2 - 6 minutes), but this possibly shows they passed through the test formally just to see what it looked like.

Some students were concerned with possible cheating, which was quite unexpected, as we planned these activities to be selfregulated. Such remarks undeliberately reminded us that being placed on the web, all teaching materials should be treated as objects of protection [22]. We fixed the vulnerability, gave praise for valuable help, and thanked for passing through the game with a good (probably winded up) score (certificates 6, 20) and doing additional work of investigation. Now the score a learner gets is always correct and can be relied on in evaluation procedures.

Teachers strictly followed the principle of confidentiality and did not divulge the scores or any personal game information, but students asked each other directly about passing through the game. They were happy to see the like-minded persons, provided help to those who asked for, withholding comments in respect to those students who did not play or did not want to share the score or discuss anything regarding the game.

\section{Conclusion}

1. Students' independent activity before we started to apply ethical principles in stimulating them to play our games was exceptionally low. It gave us the understanding that neither information technology be itself or educational computer games as an intriguing format of presenting the education materials motivated students to strive for the best results in learning English as a second language. Teachers should ethically motivate students to learn English autonomously. 
2. While ethically motivating students we retrieved statistical data of high participation of college students of Engineering (275 out of 450 ) - more than $50 \%$ of enrollees, even higher than we expected when starting.

3. The games stimulated active behavior from the specific groups of students, presented in Table 4 below in accordance with their strength.

Table 4. Specific groups of students

\begin{tabular}{|l|l|l|l|}
\hline № & Groups of students & Number & Percentage \\
\hline 1. & $\begin{array}{l}\text { students interested in IT and } \\
\text { computer games including } \\
\text { those two investigating for } \\
\text { vulnerabilities }\end{array}$ & 18 & $51.4 \%$ \\
\hline 2. & $\begin{array}{l}\text { students driven by personality } \\
\text { underlying motives }\end{array}$ & 8 & $22.8 \%$ \\
\hline 3. & interested in the topics & 6 & $17 \%$ \\
\hline 4. & $\begin{array}{l}\text { with positive attitude to the } \\
\text { language course }\end{array}$ & 2 & $5.8 \%$ \\
\hline 5. & planning to study at university & 1 & $2.9 \%$ \\
\hline
\end{tabular}

4. Since the activity was voluntary, it was evidently valued by the students with distinct intrinsic motivation in our games-related areas - IT, language, entering university (groups 1, 4, 5-60\%) and students energized with their personalities (groups 2, 3-40\%). Hence, the ethical principles are not likely to possess the motivational power by themselves but provide support in developing motivated learners, on the one hand, and on the other hand, provoke an interest from socially and psychologically responsive students contributing to their human and professional growth. And from this standpoint the student's reaction to them can serve as a kind of indicator whether they possess any sort of intrinsic motivation or do not.

5. The impetus with the least driving power appears to be orientation to higher education - only one four-year student openly declared his intention to continue education at university. The others though keeping this possibility in mind are not so definite about their professional plans for the future. This is quite in line with higher educational establishment enrolment quality monitoring data, which highlight that the amount of college graduates annually entering Russian universities is only $6-10 \%$ of the total number of enrolees.

6. The ethical skills of respect for autonomy and confidentiality provide psychological comfort to learners and cannot be measured. Still, the influence of the others on students' motivation can roughly be evaluated. Thus, the statistics and efficiency of using extra-curriculum interests, skills and competences may climb to $100 \%$ covering all the participants, providing information meaningful for students - $17 \%$ embracing students fascinated by the topics. Utility value can be estimated on the basis of such drivers as entering a university, interest to IT as a speciality, knockon effect giving $20-25 \%$.
7. The research also proves that students do need teachers' personal assessments and interest in their scores and in their personalities in general. Communication with others and possibility to be a member of a community motivate students much more than information technology itself and even educational games as a means of delivering knowledge.

\section{Conflict of Interest}

The authors declare no conflict of interest.

\section{Acknowledgment}

The authors thank the staff of the Chair of Linguodidactics of the Russian University of Transport for their support in their work.

Great thanks to the students of Serpukhov college (Moscow Region, Russia) who gave their feedback, asked questions and kindly shared their scores.

\section{References}

[1] N.V. Matveeva, "Computer Games to Fill the Gap in Learning Functional Lexis at Russian Colleges and Universities" Proceedings of 2019 International Conference "Quality Management, Transport and Information Security, Information Technologies" (IT\&QM\&IS), 639-643. 2019. http://doi.org/10.1109/ITQMIS.2019.8928440.

[2] R.R Puhan, L. Malla, S.K. Behera, "Current Ethical Issues in Teacher Education: A Critical Analysis on Pre-Service and In-service Emerging Teachers". American Journal of Educational Research, 2(12A), 1-7, 2014. http://doi.org/10.12691/education-2-12A-1.

[3] M. Sultana, "Ethics in Teaching Profession" ABC Journal of Advanced Research, 3(1), 44-50. 2014. URL: http://oaji.net/articles/2015/8141431431772.pdf

[4] O.S. Tsaregorodtseva, "Razvitiye pedagogicheskoi etiki uchitelya kak factor povysheniya effektivnosti obrazovatel'nogo protsessa v shole”. Ph.D Thesis, Murmansk, 2009. (In Russian).

[5] V.M. Grebennikova, V.V. Doroshenko "Ethics of Teaching in the Context of New Educational Paradigm", Modern Problems of Science and Education , 1(1), 1056, 2015. (In Russian).

[6] I.M. Shadrina, "Model of Building the Moral Culture of a Student - Future Teacher", The Volga district pedagogical bulletin, 6(3), 117-125, 2018. (In Russian).

[7] N.E. Skripova, "The professional ethics for teachers: perspective directions of the professional development system", Professional development system scientific bases, 2(23), pp. 28-35, 2015. (In Russian).

[8] E.V. Pyaterikova, "Pedagogical Foundations of Ethical Competence for Future Teachers", Nizhny Novgorod State Linguistic University Bulletin. Issue 21. Intercultural communication and teaching foreign languages. Challenges in Education, 181-188, 2013. (In Russian).

[9] M.V.Lamb \& M. Wedell, "Cultural contrasts and commonalities in inspiring language teaching”, Language Teaching Research, 19(2), 207-224, 2015. http://dx.doi.org/10.1177/1362168814541716.

[10] E.A. Melyokhina, Ya.R. Bobohodzhaeva, "Motivation to Learning a Foreign Language: Pedagogical Aspect", Teacher in Higher Education in XXI century, 1, 89-93, 2016. (In Russian)

[11] M. Lamb, "The motivational dimension of language teaching", Language $\begin{array}{llll}\text { Teaching, } & \mathbf{5 0}(3), & 301-346,\end{array}$ http://doi.org/10.1017/S0261444817000088.

[12] N.V. Matveeva, "Professionally Oriented Vocabulary in English Classes is Truly Fascinating”, Secondary Vocational Education, 12, 10-15, 2018. (In Russian)

[13] J. Macmurray, "Learning to be Human", Oxford Review of Education, 38, 2012 - Issue 6, 2012: Special issue: Learning to be human: the educational legacy of John Macmurray https://doi.org/10.1080/03054985.2012.745958

[14] C.A. Wolters, "Regulation of motivation: Evaluating an underemphasized aspect of self-regulated learning", Educational Psychologist, 38(4), 189$205,2003$.

[15] K.A. Noels, "Learning Japanese, learning English: Promoting motivation through autonomy, competence and relatedness", In M. Apple, D. Da Silva \& T. Fellner (Eds.), Language Learning Motivation in Japan, 15-34, 2013. http://doi.org/10.21832/9781783090518-004 
[16] A.Y. Lozovoy, E.K. Zashchitina, "Online Education: Pros and Cons", Proceedings of 2019 International Conference "Quality Management, Transport and Information Security, Information Technologies" (IT\&QM\&IS), 631-633, 2019. http://doi.org/10.1109/ITQMIS.2019.8928455.

[17] A. Assor, H. Kaplan, and C. Roth, "Choice is good, but relevance is excellent: Autonomy-enhancing and suppressing teaching behaviors predict students' engagement in schoolwork", British Journal of Educational Psychology, 72, 261-278, 2002.

[18] H. Jang, J. Reeve, \& E.L. Deci, "Engaging students in learning activities: It is not autonomy-support or structure but autonomy-support and structure", Journal of Educational Psychology, 102, 588-600, 2010.

[19] S. Aydin, "Factors causing demotivation in EFL teaching process: A case study", Qualitative Report, 17(51), 1-13, 2012.

[20] M. Bernaus, A. Wilson \& R. C., "Gardner Teachers' motivation, classroom strategy use, students' motivation and second language achievement", Porta Lingarum, 12, 25-36, 2009.

[21] J. Huang, T. Han, \& K. Schnapp, "Do High-Stakes Test Really Address English Learners' Learning Needs? - A Discussion of Issues, Concerns, and Implications", International Journal of Learning and Development, 2(1), 499-508, 2012.

[22] V.V. Zolotarev, M.N. Zhukova, "Role Model Features in Educational Serious Games", Proceedings of 2019 International Conference "Quality Management, Transport and Information Security, Information $\begin{array}{llr}\text { Technologies" } & \text { (IT\&QM\&IS), } & \text { 583-586. }\end{array}$ http://doi.org/10.1109/ITQMIS.2019.8928292 